\title{
VARIATIONS IN BIRD NESTING HABITS
}

\section{JEAN BANCROFT, 264 Campbell Street, Winnipeg, Manitoba R3N 1B5}

From observations I have made during recent years, it would appear that variations may be taking place, not only in the materials used by some birds to build their nests, but also in their nesting sites. This thought has occurred to me as a result of my birdwatching at Whytewold, Manitoba, on Lake Winnipeg, 40 miles north of the city of Winnipeg.

Formerly and still largely, the common materials used are grasses of various types, twigs of all kinds, leaves, shreds of bark, and cotton from poplar seeds; all these being produced by nature herself.

Today, however, birds are picking up materials not previously available to them. For example, I have observed that in addition to the natural materials, the following are now being used: plastic, wood shavings, strands from binder twine and string, bits of kleenex tissue, pieces of cloth, curly clumps of hair from a poodle dog, and cotton fluff from clothes dryers.

Examples from different nests are as follows:

American Robin. 1. Nest of grasses and small twigs, reinforced with mud. A four inch piece of kleenex tissue hanging down on the front of the nest. 2. Grass fibres, twigs, mud, some paper and rag woven in. 3. Grassy nest with cloth woven in and a long, one inch wide piece hanging down from nest. Another nest with green plastic hanging down.

Catbird. 1. Nest of twigs and grasses, with a piece of strong plastic near top and at front of nest, acting as a screen. 2. Twigs, string, plastic pieces.

Yellow Warbler. 1. Plant fibres, very thin strips of plastic, thin strands from binder twine, and string. 2. Silke strands from tent caterpillars, plan fibres, string. 3. Base of nest a clump o tangled white string; grass and plan fibres. 4. Plant fibres, wood shaving string.

Traill's Flycatcher. 1. Plant fibres an grasses, much cotton fluff on outsid of nest, and some kleenex hangin down. 2. Little clumps of white curl poodle hair woven in with grass an plant fibres.

Northern (Baltimore) Oriole. 1. Ne finely woven of grasses, fine stranc from binder twine. Lined with pieces fluffy cotton from clothes dryer. Crasses, plant fibres and woo shavings. 3. Plant fibres, silken stranc from tent caterpillars, plastic strip approximately $1 / 8$ inch wide. 4. Ne woven of $1 / 8$ inch plastic strips an lined with fibrous material. Variatic in shape in that it was more cup-lik and not as deep. Nest built on bouk of oak tree, overhanging a drivewa This nest was confirmed as Baltimore's by $\mathrm{H}$. Copland and Prc Sealey of the University of Manitoba had difficulty observing the nest bl realized the bird was an oriole of som kind.

Our Traill's (Alder) Flycatcher's ne higher than reported: 1 . Twelve feet $\iota$ in a crotch of a tall, thin ash tree. Fifteen feet from the ground on horizontal branch of an oak tree. Approximately 15 feet from the grour on a horizontal branch of an oak tre From what I could observe this $m$. have been the same bird which hi built and started to sit on a nest in Saskatoon bush, 12 feet from $t$ ground. That nest had been disturbr and then I observed a new nest bei built nearby in the oak. 